\title{
UPAYA PENINGKATAN PRESTASI BELAJAR PKn MELALUI METODE BERMAIN PERAN PADA SISWA KELAS IV SD NEGERI NOGOSAREN GAMPING SLEMAN
}

\author{
Nadziroh \\ Program Studi Pendidikan Sekolah Dasar FKIP Universitas Sarjanawiyata Tamansiswa \\ Jl. Batikan Tuntungan UH III/1043 Umbulharjo Yogyakarta 55167 \\ Email: Nadzre nad@yahoo.com
}

\begin{abstract}
This study is intended to increase the student's achievement and process to excute the social studies learning with Role Playing approach. This study is a Classroom Action Research (CAR) implemented to $4^{\text {th }}$ elementary students in SDN Nogosaren Gamping Sleman as the object of study. This study contains two cycles, starts from planning, implementation, monitoring, reflecting and improving. The data were collected by using learning achievement test, observations, and interviews. The data from learning achievement tests were analyzed by using the descriptive quantitative technique. The data from observations and interviews were analyzed by using the descriptive qualitative technique on the basics of the results of the observation and reflection.Findings suggest that by the Role Playing approach implementation, the civic education can get its best result. The student's score increases. It is proved by the average score in each examination. At the first cycle, the average score is 69,43 and the second cycle is $74,90$.
\end{abstract}

Key Words: Role Playing

\section{PENDAHULUAN}

Tujuan pembelajaran adalah membentuk seseorang untuk memiliki perilaku yang baik dalam peranannya sebagai anggota masyarakat dan warga negara. Sebagai anggota masyarakat ikut aktif dalam kegiatan kemasyarakatan, kehidupan yang saling menghormati, saling tolong menolong antar sesama, dan memiliki rasa empati terhadap kejadian yang berkembang dalam masyarakat sekitarnya. Sedangkan sebagai warga negara berarti patuh kepada hukum yang berlaku untuk dikembangkan dalam kehidupannya. Hasyim Muzadi mengatakan, "Bangsa ini membutuhkan cendekiawan yang tidak memisahkan antara ilmu agama dan ilmu umum. Ujungnya, pembentukan karakter." (Republika, 17 Juli 2012). Adapun langkah yang ditempuh melalui (1) siswa dibekali ilmu agama dan amaliah agama, (2) siswa diajarkan untuk menyambungkan agama dengan disiplin ilmu yang dikuasai, (3) siswa dibekali keterampilan dan profesionalisme.

Dalam proses pembelajaran, arah pendidikan saat ini dikembangkan dengan suatu pembaharuan pembelajaran yaitu menjadikan pembelajaran sebagai suatu proses yang aktif interaktif. Hal ini dikarenakan proses pembelajaran dikelas melibatkan interaksi secara langsung antara guru dengan siswa maupun siswa dengan siswa. Semua interaksi yang ada menuntut setiap komponen pendidikan terlibat secara aktif selama proses pembelajaran di kelas. Dalam hal ini komponen pendidikan di kelas adalah guru dan murid secara langsung.

Guru dalam proses pembelajaran harus memahami dan mampu menggunakan beberapa metode pembelajaran sebagai sarana membentuk siswa yang kreatif dan membuat pembelajaran menjadi suatu proses yang variatif dan menyenangkan. Hal ini sesuai dengan tuntutan kompetensi yang harus dimiliki guru sesuai dengan Permendiknas No. 16 Tahun 2007 yang mengatakan kompetensi guru kelas SD/MI adalah menerapkan berbagai pendekatan, strategi, metode, dan teknik pembelajaran yang mendidik secara kreatif dalam pembelajaran di kelas.

Begitupun dalam pembelajaran PKn terdapat banyak sekali metode pembelajaran yang dapat digunakan. Diantaranya adalah metode pembelajaran yang mengarahkan siswa untuk berhubungan dengan individu atau masyarakat yang lain. Metode pembelajaran ini dapat dioptimalkan untuk meningkatkan kemampuan siswa dalam berhubungan dengan orang lain, terlibat dalam proses demokratis dan bekerja secara produktif dalam masyarakat. Adapun metode pembelajaran yang termasuk 
dalam pendekatan pembelajaran PKn antara lain metode pembelajaran bermain peran.

Metode pembelajaran bermain peran cocok dalam pembelajaran PKn. Hal ini karena PKn pada jenjang pendidikan dasar memfokuskan kajiannya kepada hubungan antar manusia, membantu pengembangan kemampuan dalam hubungan tersebut, serta mampu menjadi warga negara yang baik dalam kehidupan demokrasi. Sedangkan metode pembelajaran bermain peran dapat membantu siswa dalam hal (1) mengembangkan keahlian dalam menjalin hubungan interpersonal, (2) menghargai pendapat orang lain, (3) mengenali adanya pendapat orang lain, (4) mengenali adanya pengaruh keputusan orang terhadap orang lain, (5) menguasai masalah yang dibicarakan dengan meniru peran orang lain yang berada dalam kejadian nyata (Savage, 2006:212). Ditambahkan pula oleh Hamzah B. Uno (2008:25) metode pembelajaran bermain peran yang dapat mendorong siswa mengekspresikan perasaanya dan bahan melapaskan, serta merupakan proses psikologis yang melibatkan sikap, nilai, dan keyakinan.

Melalui pembelajaran yang variatif, maka hasil belajar PKn menjadi optimal. Artinya hasil pembelajaran PKn bagi siswa diperoleh nilai yang tinggi, minimum telah didapatkan hasil yang sesuai dengan apa yang dituntut standar isi dan standar kompetensi lulusan.

\section{TINJAUAN PUSTAKA}

\section{A. Pengertian Hasil Belajar}

Menurut Nana Sudjana (2002: 22) bahwa hasil belajar adalah kemampuankemampuan yang dimiliki siswa setelah menerima pengalaman belajarnya. Hal senada disampaikan oleh Dimyati \& Mujiono (2009: 3) bahwa hasil belajar merupakan hasil dari suatu interaksi tindak belajar dan tindak mengajar. Dari sisi guru, tindak mengajar diakhiri dengan proses evaluasi hasil belajar, dari segi siswa, hasil belajar merupakan realisasi atau pemekaran dari kecakapan-kecakapan potensial atau kapasitas yang dimiliki seseorang (Nana Syaodih, 2009:102).

\section{B. Klasifikasi Hasil Belajar}

Pengklasifikasian hasil belajar dalam sistem pendidikan nasional, rumusan tujuan pendidikan menggunakan klasifikasi hasil belajar dari Bloom (suharsimi, 1994:112), yang secara garis besar membaginya menjadi 3 ranah yang dikenal dengan istilah taksonomi Bloom yaitu: ranah kognitif, ranah afektif dan ranah psikomotorik. Ketiga ranah tersebut menjadi objek dalam penilain hasil belajar, dimana masing-masing ranah terdiri dari sejumlah aspek yang saling berkaitan dan alat penilaian untuk setiap ranah yang mempunyai karakteristik sendiri-sendiri sebab setiap ranah berbeda dalam cakupan dan hakikat yang terkandung di dalamnya.

\section{Cara Mengukur Hasil Belajar}

Pengetahuan yang terdapat pada diri siswa merupakan suatu prestasi utama dan penting. Oleh karena itu, dalam merencanakan pembelajaran perlu dimasukkan cara mengukur hasil belajar. Agar guru mengetahui tingkat pengetahuan siswa, maka guru harus menguji hasil belajar siswa tersebut dengan menggunakan tes, yaitu tes hasil belajar. Siswa dikatakan tuntas dalam belajarnya apabila nilai siswa telah mencapai taraf penguasaan minimal yang diterapkan bagi setiap unit bahan yang dipelajarinya. Di SD Negeri Nogosaren Gamping Sleman pada mata pelajaran PKn standar ketuntasannya yaitu 7.Tes hasil belajar dibedakan menjadi 3 yaitu:ulangan harian, tes mid semester dan tes akhir semester.

\section{Faktor yang Mempengaruhi Hasil Belajar}

Dalam proses belajar mengajar, keberhasilan dan kegagalan tidak dapat dilihat dari satu faktor saja, tetapi perlu memandang dari beberapa segi atau faktor yang mempengaruhi. Menurut Sri Rumini (2006: 60) menyatakan bahwa faktor-faktor yang mempengaruhi proses dan hasil belajar meliputi faktor yang berasal dari diri individu dan faktor yang berasal dari luar.

\section{E. Pengertian metode bermain peran}

Metode bermain peran adalah berperan atau memainkan peranan dalam dramatisasi masalah sosial atau psikologis.

Bermain peran adalah salah satu bentuk permainan pendidikan yang di gunakan unutk menjelaskan perasaan, sikap, tingkah laku dan nilai, dengan tujuan untuk menghayati perasaan, sudut pandangan dan cara berfikir orang lain (Depdikbud, 1998:37).

Proses belajar dengan menggunakan metode bermain peran diharapkan siswa mampu menghayati tokoh yang dikehendaki, keberhasilan siswa dalam menghayati peran itu akan menetukan apakah proses pemahaman, 
penghargaan dan identifikasi diri terhadap nilai berkembang: (Hasan, 1996: 266).

\section{Tujuan Penggunaan Bermain Peran}

Tujuan dari penggunaan metode bermain peran adalah sebagai berikut :

1. Untuk motivasi siswa,

2. Untuk menarik minat dan perhatian siswa,

3. Memberikan kesempatan kepada siswa untuk mengeksplorasi situasi dimana mereka mengalami emosi, perbedaan pendapat dan permasalahan dalam lingkungan kehidupan sosial anak

4. Menarik siswa untuk bertanya,

5. Mengembangkan kemampuan komusikasi siswa,

6. Melatih siswa untuk berperan aktif dalam kehidupan nyata

\section{Langkah-langkah dan persiapan bermain peran}

Agar proses pelaksanaan pembelajaran PKn dengan menggunakan metode bermain peran tidak mengalami kaku, maka perlu adanya langkah-langkah yang harus kita pahami terlebih dahulu ( Dahlan ; 1984) adalah sebagai berikut :

1. Identifikasi masalah dengan cara memotivasi para peserta didik,

2. Memilih tema,

3. Menyusun skenario pembelajaran,

4. Pemeranan,

5. Tahapan diskusi dan evaluasi,

6. Melakukan pemeranaan ulang, melakukan diskusi dan evaluasi tahap 2,

7. Membagi pengalaman dan menarik generalisasi

\section{Metode Bermain Peran Dalam Pembelajaran PKn di Sekolah Dasar}

Penggunaan metode bermain peran tidak terlepas dari kegiatan tanya jawab dan evalusi. Pembelajaran PKn dengan menggunakan bermain peran siswa akan menemukan bahwa dengan pemeranan para pemain dan pengamat memiliki kesempatan untuk merefleksikan apa yang sedang terjadi.

Bermain peran dapat digunakan untuk melatih para siswa mengekspesikan masalahmasalah hubungan manusia, serta untuk mengilustrasikan bagaimana bermain peran bisa digunakan untuk mengembangkan kemampuan perasaan, sikap dan nilai.

\section{Macam dan jenis metode bermain peran}

Metode pengajaran simulasi terbagi menjadi 3 kelompok seperti yang dikemukakan oleh Ali (1996:83) berikut ini ; (1) Sosiodrama : semacam drama sosial berguna untuk menanamkan kemampuan menganalisa situasi sosial tertentu, (2) Psikodrama : hampir mirip dengan sosiodrama. Perbedaan terletak pada penekannya. Sosia drama menekankan kepada permasalahan sosial, sedangkan psikodrama menekankan pada pengaruh psikologisnya dan (3) Role-Playing : role playing atau bermain peran bertujuan menggambarkan suatu peristiwa masa lampau.

\section{F. Pengertian Kewarganegaraan (PKn)}

Pendidikan

Pendidikan merupakan program pendidikan yang memiliki misi untuk mengembangkan nilai luhur dan moral yang berakar pada budaya dan keyakinan bangsa Indonesia yang memungkinkan dapat diwujudkannya dalam perilaku kehidupan sehari-hari.

Secara epistimologis, pendidikan kewarganegaraan dikembangkan dalam tradisi citizenship education yang tujuannya sesuai dengan tujuan nasional masing-masing Negara namun secara umum tujuan Negara mengembangkan pendidikan kewarganegaraan (PKn) adalah agar setiap warga Negara menjadi warga Negara yang baik (to be good citizens) yakni warganegara yang memiliki kecerdasan (Civic Intelligence) baik intelektual, emosional, sosial, maupun spiritual; memiliki rasa bangga dan tanggung jawab (Civic Responsibility); dan mampu berpartisipasi dalam kehidupan bermasyarakat dan bernegara (Civic Participation) agar tumbuh rasa kebangsaan dan cinta tanah air (Maftuh dkk,2005:320).

\section{Tujuan Pendidikan Kewarganegaraan (PKn)}

Tujuan pembelajaran mata pelajaran Pendidikan Kewarganegaraan, menurut Mulyasa (2007) adalah untuk menjadikan siswa:

1 Mampu berpikir secara kritis, rasional, dan kreatif dalam menanggapi persoalan hidup maupun isu kewarganegaraan di negaranya.

2 Mau berpartisipasi dalam segala bidang kegiatan, secara aktif dan bertanggung jawab, sehingga bisa bertindak secara cerdas dalam semua kegiatan, dan 
3 Bisa berkembang secara positif dan demokratis, sehingga mampu hidup bersama dengan bangsa lain di dunia dan mampu berinteraksi, serta mampu memanfaatkan teknologi informasi dan komunikasi dengan baik. Hal ini akan mudah tercapai jika pendidikan nilai moral dan norma tetap ditanamkan pada siswa sejak usia dini, karena jika siswa sudah memiliki nilai moral yang baik, maka tujuan untuk membentuk warga negara yang baik akan mudah diwujudkan.

\section{Visi dan Misi PKn}

Sukardi (2006:173) mengemukakan bahwa pendidikan kewaganegaraan (PKn) ke depan mempunyai visi menjadi program pendidikan sekolah yang terintegrasi dalam rangka melahirkan warga negara yang cerdas, bertanggung jawab, demokratis, berbudi pekerti luhur, bermoral tinggi dan mandiri, serta terampil dan partisipatif dalam kehidupan bermasyarakat, berbangsa, dan bernegara. Baik di tingkat lokal, nasional, dan global dengan tetap berlandaskan kepada nilai-nilai dan ketentuan-ketentuan dalam Pancasila dan UUD 1945. Dengan visi ini hendaknya mampu menghasilkan warga negara yang mampu berfikir global tetapi tetap respek dan bertanggung jawab untuk melaksanakan komitmen kehidupan berbangsa dan bernegara Indonesia.

\section{Ruang Lingkup PKn}

Pengembangan Kurikulum Tingkat Satuan Pendidikan (KTSP) yang beragam mengacu pada standar nasional pendidikan untuk menjamin pencapaian tujuan Pendidikan Nasional. Standar Nasional Pendidikan terdiri atas Standar isi, proses, kompetensi lulusan, tenaga kependidikan, sarana dan prasarana, pengelolaan, pembiayaan, dan penilaian Pendidikan. Dua dari kedelapan standar nasional pendidikan tersebut, yaitu Standar Isi (SI) dan Standar Kompetensi Lulusan (SKL) merupakan acuan utama bagi satuan pendidikan dalam mengembangkan kurikulum.

Berikut disajikan standar isi mata pelajaran Pendidikan Kewarganegaraan, yang meliputi Standar Kompetensi dan Kompetensi Dasar. Dalam standar Isi (BSNP, 2006: 271) dijelaskan juga mengenai ruang lingkup Pendidikan Kewarganegaraan, yakni meliputi aspek-aspek sebagai berikut: Persatuan dan kesatuan Bangsa, Norma, hukum dan peraturan, Hak Asasi Manusia Kebutuhan warga negara Konstitusi Negara Kekuasaan dan politik Pancasila dan Globalisai.

\section{G. Kerangka Pikir}

Hasil belajar merupakan salah satu unsur yang sangat penting dari sikap akademik siswa dalam kaitannya dengan penyelenggaraan pendidikan di SD. Dengan minat belajar yang besar terhadap kegiatan pembelajaran yang sungguh-sungguh untuk menggali keterampilan dan mencapai pemahaman materi pelajaran PKn merupakan bagian dari sikap akademik setiap siswa. Keberhasilan peningkatan prestasi belajar pada khususnya dan pendidikan pada umumnya, harus melibatkan banyak faktor, tidak hanya guru saja, tetapi juga siswa, kurikulum, fasilitas sekolah, dukungan orang tua, dukungan pemerintah, dan sebagainya.

Guru sebagai pemegang kendali di kelas, mempunyai tanggung jawab yang besar. Oleh karena itu guru dituntut untuk mencari model atau metode pembelajaran yang dapat membawa pengaruh besar pada pola pikir siswa dalam meningkatkan minat serta prestasi belajar siswa, sekaligus meningkatkan mutu pendidikan di Indonesia. Salah satu upaya untuk meningkatkan hasil belajar PKn adalah dengan menggunakan variasi metode pembalajaran, diantaranya dengan metode bermain peran.

Penggunaan metode pembelajaran yang bervariasi dan penggunaan media yang baik dan tepat oleh guru, sangat bermanfaat untuk mendapatkan hasil belajar yang optimal. Hal tersebut disebabkan karena tanpa metode pembelajaran yang tepat, kecil kemungkinan akan dapat meningkatkan hasil belajar siswa pada mata pelajaran PKn. Akan tetapi, harus ditunjang oleh kemampuan guru dalam menggunakan metode pembelajaran yang tepat dan menggunakan media pembalajaran yang tepat pula. Dari beberapa metode pembelajaran yang ada, maka dalam penelitian ini dipilih metode pembelajaran bermain peran.

\section{METODE PENELITIAN}

Penelitian ini menggunakan penelitian tindakan kelas (Classroom action research) yang merupakan kegiatan atau tindakan yang mengujicobakan suatu ide ke dalam praktik atau situasi nyata dalam skala yang mikro, yang diharapkan kegiatan tersebut mampu memperbaiki dan meningkatkan kualitas belajar 
mengajar (Suwarsih Madya, 2006: 8-11). Penelitian ini menggunakan desain penelitian tindakan kelas yang bersifat kolaboratif yang didasarkan pada permasalahan-permasalahan yang timbul dalam proses kegiatan pembelajaran di kelas dimana guru itu mengajar serta diamati oleh peneliti.

Penelitian tindakan kelas terjadi melalui proses yang dinamis dan saling melengkapi yang terdiri atas kegiatan atau tahapan penting yaitu perencanaan, pelaksanaan, pengamatan dan refleksi (Mc Taggart, 1993:32).

\section{HASIL PENELITIAN}

\section{A. Siklus I}

Siklus I terdiri dari 4 (empat) pertemuan, dengan waktu masing-masing $2 \times 45$ menit, yaitu: tanggal 11, 18, 25 dan 31 Oktober 2013. Pokok kajian pada siklus I ini adalah Sistem pemerintahan desa dan Kecamatan yang terbagi dalam sub pokok bahasan yaitu: (1) lembaga pemerintahan desa dan Kecamatan, (2) Susunan pemerintahan desa dan kecamatan.Pada pertemuan terakhir, selama 40 menit dilakukan penilaian terhadap hasil belajar PKn.

Sesuai dengan kaidah pembelajaran dengan penerapan model pembelajaran bermain peran, tahapan pelaksanaan tindakan diawali dengan presentasi kelas oleh guru, dilanjutkan dengan kerja tim. Di akhir siklus dilakukan kuis secara individual.

Pada pertemuan pertama selama 90 menit, proses pembelajaran masih lebih didominasi guru. Dari hasil pengamatan diperoleh: waktu yang digunakan aktivitas guru 45 menit $(65,11 \%)$ dan aktivitas siswa 35 menit (38,89\%). Dari 30 siswa yang hadir, jumlah siswa yang aktif memperhatikan adalah 16 siswa (53,33\%), jumlah siswa yang aktif berpartisipasi adalah 3 siswa (10\%), dan jumlah siswa yang aktif bekerja sama adalah 17 siswa $(56,66 \%)$.

Dari pengamatan pertemuan kedua selama 90 menit, diperoleh: waktu yang digunakan untuk aktivitas guru adalah 35 menit dan waktu yang digunakan untuk aktivitas siswa juga 45 menit. Dari 30 siswa yang hadir, diperoleh jumlah siswa yang aktif memperhatikan adalah 19 siswa (63,33\%), jumlah siswa yang aktif berpartisipasi adalah 5 siswa $(16,66 \%)$, dan jumlah siswa yang aktif bekerja sama adalah 19 siswa (63,33\%).

Pada pertemuan ketiga selama 90 menit, proses pembelajaran sudah lebih didominasi siswa. Dari hasil pengamatan diperoleh waktu yang digunakan untuk aktivitas guru adalah 35 menit dan untuk aktivitas siswa juga 45 menit. Dari 30 siswa yang hadir, diperoleh banyak siswa yang aktif memperhatikan adalah 20 siswa (66,66\%), banyak siswa yang aktif berpartisipasi adalah 4 siswa(13,33\%), dan banyak siswa yang aktif bekerja sama adalah 21 siswa (70\%).

Pada pertemuan keempat,diawali pembelajaran selama 45 menit kemudian evaluasi 45 menit. Dari hasil pengamatan diperoleh waktu yang digunakan untuk pembelajaran adalah 45 menit, diperoleh: waktu untuk aktivitas guru adalah 10 menit dan untuk aktivitas siswa 35 menit. Dari 30 siswa yang hadir, diperoleh banyak siswa yang aktif memperhatikan adalah 21 siswa (70\%), banyak siswa yang aktif berpartisipasi adalah 5 siswa $(16,66 \%)$, dan banyak siswa yang aktif bekerja sama adalah 21 siswa (70\%).

Di akhir siklus I diadakan evaluasi yang dikerjakan secara individu untuk melihat tingkat penguasaan siswa terhadap materi yang dipelajari. Dari tes yang dilakukan setelah akhir siklus I, jumlah siswa yang mencapai daya serap diaatas $70 \%$ sebanyak 20 siswa $(66,66 \%)$ sedangkan siasanya 10 siswa $(33,33 \%)$ berada di bawah $70 \%$. Nilai rata-rata pada siklus I yaitu 69,43 masih di bawah nilai ketuntasan minimal yaitu 70 .

\section{Refleksi Siklus I}

Setelah selesai melakukan proses pembelajaran siklus I, penulis, guru dan kolaborator mengadakan refleksi. Bahan refleksi adalah: hasil pengamatan, masukan dari siswa, masukan dari penulis, dan masukan dari guru

Kesimpulan yang diperoleh dari siklus I adalah: (1) Pembelajaran yang dilakukan sudah sesuai dengan tahapan yang harus dilakukan dalam pembelajaran dengan model bermain peran, (2) Sebagian besar siswa senang melakukan pembelajaran dengan dengan model bermain peran,, (3) Dominasi guru dalam pembelajaran semakin menurun, sedangkan aktivitas siswa meningkat, (4) Perhatian siswa masih fluktuatif, tetapi ada kecenderungan meningkat, (5) Partisipasi siswa dalam pembelajaran masih fluktuatif, tetapi ada kecenderunagn meningkat, (6) Kerja sama siswa dalam kerja kelompok semakin meningkat, walaupun masih ada siswa dengan kemampuan rendah menggantungkan diri pada kelompok yang memiliki kemampuan tinggi, (7) Banyak siswa yang mencapai ketuntasan 
belajar adalah 20 siswa dari 30 siswa atau $66,66 \%,(8)$ Perhatian kepedulian siswa, serta kemampuan pengelolaan kelas dari guru meningkat.

Masalah yang muncul dan perlu dicari penyelesaian adalah: (1) Ada siswa yang belum aktif dalam jalannya bermain peran, (2) waktu yang digunakan untuk menyelesaikan materi dengan model pembelajaran bermain peran relatif lebih banyak, (3) Masih membutuhkan waktu bagi siswa untuk memahami tugas dan karakter dalam bermain peran. Hal ini dapat mengurangi waktu efektif pembelajaran.

\section{B. Siklus II}

Siklus II terdiri dari 4 (empat) pertemuan, dengan wktu masing-masing $2 \times 45$ menit, yaitu: tanggal 8, 15, 22, 29 Desember 2013 . Pada pertemuan terakhir, selama 45 menit dilakukan penilaian terhadap hasil belajar PKn. Pokok bahasan pada siklus II ini adalah Sistem Pemerintahan Kabupaten, Kota dan Provinsi yang meliputi 2 sub bab yaitu (1)Lembaga Pemerintahan Kabupaten, Kota dan Provinsi, (2) Susunan Organisasi Kabupaten, Kota dan Provinsi.

Pada pertemuan pertama siklus II selama 90 menit, proses pembelajaran dominasi guru sudah berkurang. Dari hasil pengamatan diperoleh: waktu yang digunakan aktivitas guru 35 menit $(38,88 \%)$ dan aktivitas siswa 55 menit $(61,11 \%)$. Dari 30 siswa yang hadir, jumlah siswa yang aktif memperhatikan adalah 26 orang $(86,66 \%)$, jumlah siswa yang aktif berpartisipasi adalah 6 siswa (20\%), dan jumlah siswa yang aktif bekerja sama adalah 22 siswa (73,33\%).

Dari pengamatan pertemuan kedua selama 90 menit, diperoleh: waktu yang digunakan untuk aktivitas guru adalah 20 menit dan waktu yang digunakan untuk aktivitas siswa juga 60 menit. Dari 30 siswa yang hadir, diperoleh jumlah siswa yang aktif memperhatikan adalah 27 siswa (74,29\%), jumlah siswa yang aktif berpartisipasi adalah 56siswa $(14,29 \%)$, dan jumlah siswa yang aktif bekerja sama adalah 24 siswa $(71,43 \%)$.

Pada pertemuan ketiga selama 90 menit, proses pembelajaran sudah lebih didominasi siswa. Dari hasil pengamatan diperoleh waktu yang digunakan untuk aktivitas guru adalah 20 menit dan untuk aktivitas siswa juga 70 menit. Dari 30 siswa yang hadir, diperoleh jumlah siswa yang aktif memperhatikan adalah 27 siswa (82,86\%), banyak siswa yang aktif berpartisipasi adalah 7 siswa $(8,57 \%)$, dan jumlah siswa yang aktif bekerja sama adalah 25 siswa $(71,43 \%)$.

Pada pertemuan keempat selama 45 menit kemudian evaluasi 45 menit. Dari hasil pengamatan diperoleh waktu yang digunakan untuk pembelajaran adalah 45 menit, diperoleh: waktu untuk aktivitas guru adalah 10 menit dan untuk aktivitas siswa juga 35 menit. Dari 30 siswa yang hadir, diperoleh jumlah siswa yang aktif memperhatikan adalah 26 siswa (86,66\%), jumlah siswa yang aktif berpartisipasi adalah 7 siswa $(23,33 \%)$, dan jumlah siswa yang aktif bekerja sama adalah 25 siswa (83,33\%).

Di akhir siklus II diadakan evaluasi yang dikerjakan secara individu untuk melihat tingkat penguasaan siswa terhadap materi yang dipelajari. Dari hasil evaluasi siswa, dapat ditentukan peningkatan nilai individu dan skor kelompok. Penghargaan individu bertujuan untuk memberikan dorongan pada siswa agar berupaya mencapai perolehan hasil belajar yang maksimal. Hal ini dapat dicapai jika siswa tersebut bekerja lebih baik dan diharapkan memperoleh hasil belajar yang selalu meningkat dari perolehan hasil belajar sebelumnyayaitu pada siklus I nilai rata-rata yaitu: 69,43 mengalami kenaikan pada siklus II nilai rata-rata yaitu: 74,90 .

\section{Refleksi Siklus II}

Setelah selesai melakukan proses pembelajaran siklus II, peneliti, guru dan kolaborator mengadakan refleksi untuk menilai pembelajaran dengan model bermain peran. Bahan refleksi adalah: hasil pengamatan, masukan dari siswa, masukan dari peneliti, dan masukan dari guru.

Kesimpulan yang diperoleh dari siklus II adalah: (1) Pembelajaran yang dilakukan sudah sesuai dengan tahapan yang harus dilakukan dalam pembelajaran dengan model bermain peran, (2) Sebagian besar siswa senang melakukan pembelajaran dengan model bermain peran, (3) Dominasi guru dalam pembelajaran semakin menurun, sedangkan aktivitas siswa meningkat, (4) Perhatian siswa sudah mengalami peningkatan, (5) Partisipasi siswa dalam pembelajaran masih fluktuatif, tetapi ada kecenderunagn meningkat, (6) Kerja sama siswa dalam kerja kelompok semakin meningkat, walaupun masih ada siswa dengan kemampuan rendah menggantungkan diri pada kelompok yang memiliki kemampuan tinggi, (7) Banyak siswa yang mencapai ketuntasan 
belajar adalah 26 siswa dari 30 siswa atau $86,66 \%$, (8) Waktu yang digunakan untuk menyelesaikan materi pelajaran lebih banyak dari yang direncanakan, (9) Perhatian kepedulian siswa, serta kemampuan pengelolaan kelas dari guru meningkat

\section{Pembahasan}

A. Penerapan model pembelajaran bermain peran

Pada siklus I, proses pembelajaran dengan model pembalajaran bermain peran masih belum sempurna. Waktu yang dibutuhkan untuk menyelesaikan 1 (satu) sub kompetensi lebih banyak dari waktu yang disediakan, yang biasanya menggunakan pendekatan yang konvensional. Pada siklus II proses pembelajaran dengan penerapan model pembelajarn bermain peran sudah menunjukkan sempurna.

\section{B. Peningkatan keaktifan, perhatian, partisipasi dan kerjasama siswa}

Keaktifan siswa yang ditandai dengan dominasi siswa dalam pembelajaran, perhatian siswa, partisipasi siswa, dan kerjasama siswa, sebelum dan selama dilakukan tindakan, dapat diamati dalam tabel berikut ini:

\begin{tabular}{clcc}
\multicolumn{3}{c}{ Tabel 1. Keaktifan Siswa dan Guru } \\
\hline No & URAIAN & \multicolumn{2}{c}{ PRESENTASE } \\
\cline { 3 - 4 } & & Siklus I & $\begin{array}{c}\text { Siklus } \\
\text { II }\end{array}$ \\
\hline 1 & $\begin{array}{l}\text { Waktu guru } \\
\text { aktif }\end{array}$ & 43,06 & 25,21 \\
2 & Waktu siswa & 56,94 & 76,87 \\
& aktif & & \\
3 & Perhatian & 82,48 & 92,34 \\
4 & Partisipasi & 8,75 & 26,65 \\
5 & Kerjasama & 69,89 & 97,34 \\
\hline
\end{tabular}

Berdasarkan tabel di atas, dapat dilihat bahwa waktu siswa aktif dalam pembelajaran dari waktu ke waktu mengalami peningkatan. Dominasi guru semakin berkurang sedangkan dominasi siswa semakin bertambah. Peningkatan perhatian dan kerjasama siswa cukup signifikan. Partisipasi siswa sudah mengalami kecenderungan meningkat, walaupun belum bisa maksimal.

\section{Peningkatan Hasil Belajar Siswa}

Peningkatan hasil belajar siswa secara individu dapat diamati dari tabel berikut ini:
Tabel 2. Peningkatan Hasil Belajar Siswa

\begin{tabular}{|c|c|c|c|c|}
\hline NO & NAMA & PRETEST & SIKLUS & $\begin{array}{c}\text { SIKLUS } \\
2\end{array}$ \\
\hline 1 & MIA & 35 & 40 & 45 \\
\hline 2 & ZIS & 40 & 95 & 80 \\
\hline 3 & VEB & 45 & 80 & 80 \\
\hline 4 & DEW & 55 & 75 & 75 \\
\hline 5 & DIN & 85 & 90 & 90 \\
\hline 6 & VEL & 80 & 90 & 95 \\
\hline 7 & AYU & 75 & 75 & 80 \\
\hline 8 & TFK & 55 & 50 & 60 \\
\hline 9 & YAS & 50 & 55 & 70 \\
\hline 10 & RIS & 60 & 80 & 85 \\
\hline 11 & MUH & 40 & 65 & 70 \\
\hline 12 & RIY & 70 & 70 & 75 \\
\hline 13 & KUR & 60 & 65 & 70 \\
\hline 14 & PAN & 50 & 65 & 75 \\
\hline 15 & DAM & 65 & 70 & 75 \\
\hline 16 & HAF & 70 & 70 & 70 \\
\hline 17 & ANI & 50 & 50 & 70 \\
\hline 18 & ANU & 67 & 70 & 71 \\
\hline 19 & DIM & 70 & 67 & 72 \\
\hline 20 & DRI & 60 & 63 & 73 \\
\hline 21 & EFE & 76 & 73 & 80 \\
\hline 22 & EKA & 70 & 70 & 73 \\
\hline 23 & ELK & 77 & 80 & 73 \\
\hline 24 & ELY & 60 & 53 & 70 \\
\hline 25 & FAR & 63 & 67 & 73 \\
\hline 26 & FER & 73 & 70 & 77 \\
\hline 27 & FIS & 70 & 70 & 80 \\
\hline 28 & HUZ & 70 & 68 & 73 \\
\hline 29 & IKE & 73 & 77 & 80 \\
\hline \multirow[t]{3}{*}{30} & $\mathrm{IKH}$ & 73 & 70 & 87 \\
\hline & Jumlah & 1887 & 2083 & 2247 \\
\hline & $\begin{array}{l}\text { Rata- } \\
\text { rata }\end{array}$ & 62,9 & 69,43 & 74,90 \\
\hline
\end{tabular}

Dari tabel di atas dapat diketahui bahwa dari hasil belajar kegiatan pretest, siklus I dan siklus II secara umum hasil belajar siswa secara individu cenderung mengalami peningkatan.

\section{KESIMPULAN DAN SARAN}

\section{A. Kesimpulan}

Dari pembahasan diperolah beberapa kesimpulan sebagai berikut:

Penerapan model pembelajaran bermain peran pada pembelajaran PKn di kelas IV SD Negeri Nogosaren Gamping Sleman dapat meningkatkan prestasi belajar siswa. Hal ini 
dapat dibuktikan dengan nilai rata-rata pada evaluasi tiap siklus, siklus I nilai rata-rata yaitu: 69,43 mengalami peningkatan pada siklus II nilai rata-rata yaitu: 74,90.

\section{B. Saran}

Berdasarkan penelitian yang sudah dilakukan, ada beberapa saran yang penulis sampaikan, antara lain:

1. Saran Kepada Sekolah

Model pembelajaran bermain peran sebagai salah satu pendekatan pembelajaran yang telah terbukti mampu meningkatkan prestasi belajar PKn. Selain itu, perhatian dan kepedulian guru juga meningkat. Hal ini perlu menjadi perhatian sekolah agar mengadakan sosialisasi model pembelajaran bermain peran dan memberikan kesempatan, fasilitas serta motivasi kepada para guru sehingga lebih memahami model pembelajaran bermain peran .

Secara umum hendaknya dikembangkan budaya penelitian pada setiap guru untuk mampu melihat permasalahan dalam proses pembelajaran, mampu menganalisa dan mampu melakukan Penelitian Tindakan Kelas guna peningkatan efektifitas mata pelajaran yang diampu.

2. Saran Kepada Guru

Kepada para guru disarankan agar melaksanakan pembelajaran dengan model bermain peran. Dengan model pembelajaran bermain peran pencapaian hasil pembelajaran akademik meningkat. Pendekatan model pembelajaran bermain peran juga mampu meningkatkan rasa kebersamaan antar teman, tanggung jawab, kerja sama dan jiwa sosial siswa.

3. Saran Kepada peneliti Lain.

Melalui model pembelajaran bermain peran ditemukan bahwa mampu meningkatkan perhatian, partisipasi, kerjasama, ketuntasan belajar dan keaktifan siswa serta perhatian dan kepedulian guru. Hal ini dapat digunakan sebagai informasi secara empirik yang dapat digunakan sebagai acuan bagi para peneliti lain. Disarankan kepada peneliti lain, agar lebih cermat dalam observasi awal sehingga mampu menemukan permasalahan yang tepat sehingga mampu melahirkan hipotesis tindakan yang tepat dan pada gilirannya mampu merumuskan solusi yang optimal
Dahlan MD. (1990) Model-model Mengajar, Bandung; Diponogoro.

David, I.K (1987) Pengelolaan Belajar, Jakarta: David_MC. Coy, Inc

Dahar. RW. (1996) Teori-teori Belajar, Jakarta ; Erlangga.

Depdikbud (1999). Penelitian Tindakan Kelas, Jakarta : Depdikbud

Hasan, B. 2002. Kurikulum dan pembelajaran. Jakarta:Bumi Aksara.

Kemmis, S., \& Mc Taggart, R. 1990. The Action research Reader. Australia: Deakin University Press.

Miles, M.B., \& Huberman, A, M. 1992. Analisis data Kualitatif. (terjemahan Tjetjep Rolindi Rahidi). Jakarta: Universitas Indonesia Press.

Nana Syaodih Sukmadinata. 2007. Metode Penelitian Pendidikan. Bandung: remaja Rosdakarya.

Peraturan Menteri Pendidikan Nasional Republik Indonesia Nomor 22 Tahun 2006 tentang Standar Isi untuk satuan Pendidikan Dasar dan Menengah.

Permendiknas No. 16 Tahun 2007

Suharsimi Arikunto. 1989. Manajemen Penelitian. Jakarta: Proyek Pengembangan Lembaga Pendidikan tenaga Kependidikan Depdikbud.

Savage, Tom V. 1996. Effective teaching in elementary social studies. (Third edition). New jersey:Englewood Cliffs

Suwarsih Madya. 2006. Panduan penelitian tindakan. Yogyakarta: Lemlit IKIP

\section{DAFTAR PUSTAKA}

